\title{
Characterisation of Organomineral Fertilisers Derived from Nutrient-Enriched Biosolids Granules
}

\author{
Diogenes L. Antille, ${ }^{1,2}$ Ruben Sakrabani, ${ }^{1}$ Sean F. Tyrrel, ${ }^{1}$ \\ Minh S. Le, ${ }^{3}$ and Richard J. Godwin ${ }^{4}$ \\ ${ }^{1}$ School of Applied Science, Cranfield University, Cranfield, Bedfordshire MK43 0AL, UK \\ ${ }^{2}$ University of Southern Queensland, National Centre for Engineering in Agriculture, Building Z2, West Street, \\ Toowoomba, QLD 4350, Australia \\ ${ }^{3}$ United Utilities Group PLC, Lingley Mere Business Park, Warrington WA5 3LP, UK \\ ${ }^{4}$ Harper Adams University, Newport, Shropshire TF10 8NB, UK
}

Correspondence should be addressed to Diogenes L. Antille; Dio.Antille@usq.edu.au

Received 23 June 2013; Accepted 30 August 2013

Academic Editor: Leonid Perelomov

Copyright (C) 2013 Diogenes L. Antille et al. This is an open access article distributed under the Creative Commons Attribution License, which permits unrestricted use, distribution, and reproduction in any medium, provided the original work is properly cited.

\begin{abstract}
Organomineral fertilisers (OMFs) were produced by coating biosolids granules with urea and potash. Two OMF formulations with $\mathrm{N}: \mathrm{P}_{2} \mathrm{O}_{5}: \mathrm{K}_{2} \mathrm{O}$ compositions: $10: 4: 4\left(\mathrm{OMF}_{10}\right)$ and $15: 4: 4\left(\mathrm{OMF}_{15}\right)$ were developed for application in grassland and arable crops. Routine fertiliser analyses were conducted on four batches of OMF and biosolids granules and compared with a sample of urea to determine key physical and chemical properties of the materials which affect handling and spreading, soil behaviour, and fertiliser value. Bulk and particle densities were in the range of 608 to $618 \mathrm{~kg} \mathrm{~m}^{-3}$, and 1297 to $1357 \mathrm{~kg} \mathrm{~m}^{-3}$, respectively. Compression tests showed that OMF particles undergo deformation followed by multiple failures without disintegration of the granules when vertical load was applied. Static particle strength was between 1.18 and $4.33 \mathrm{~N} \mathrm{~mm}^{-2}$ depending on the particle diameter. The use of a model for fertiliser particle distribution studies showed that OMF granules should be between 1.10 and $5.50 \mathrm{~mm}$ in diameter with about $80 \%$ of the particles in the range of 2.25 to $4.40 \mathrm{~mm}$ to enable application at $18 \mathrm{~m}$ tramline spacing. This research utilises novel technology to improve the fertiliser value of biosolids, reduce disposal costs, and deliver a range of environmental benefits associated with recycling.
\end{abstract}

\section{Introduction}

1.1. The Need for Recycling. The production of sewage sludge (biosolids) in England and Wales is estimated to be 1.6 million tonnes (dry solids) per year [1] while this amount exceeds 10 million tonnes (dry solids) per year in the European Union (EU) [2]. Current levels of sludge production are set to increase due to the growth of the population and continuous adoption of improved technologies which are introduced to comply with standards required for the treatment of effluents. The quantity of sewage sludge recycled to agriculture varies considerably between EU member states. The UK and Ireland recycle approximately $70 \%$ and $90 \%$, respectively, while Finland, Slovenia, Sweden, Holland, Greece, and Belgium recycle very low quantities or no sewage sludge to agriculture
[3]. Conventional routes for disposal of sewage sludge include landfill and incineration which are considered to be unsustainable and therefore being progressively restricted. In this respect, the EU Landfill Directive 99/31/EC [4] requires reduction of $35 \%$ of biodegradable waste by 2020 of that generated in 1995 while the UK Government is committed to cut back $\mathrm{CO}_{2}$ emission by $20 \%$ [5] which narrows the opportunities for increased disposal through incineration. Expanding incineration infrastructure to deal with increased sewage production can be cumbersome due to difficulties arising from approval of planning permissions and because of strong public opposition.

Recycling of biosolids to agricultural land is relatively less expensive compared with other disposal practices, that is, $30 \%$ to $40 \%$ compared with incineration and landfill per 
tonne of raw sludge (dry solids) [6], and it is regarded as the best practicable environmental option in most circumstances [7]. The practice of recycling supports the waste management hierarchy [1] and the principles of sustainable intensification of agriculture [8]. It is envisaged that the use of organic-based fertiliser materials will increase in the near future [9] as a result of technological developments that may enable production of high-quality products, improvements in application techniques for field spreading and specialist equipment, and cost advantages compared with mineral fertilisers.

The expected increase in the global population with the associated rise in demand for food and energy will increase the reliance on fertiliser inputs [10]. The global demand for $\mathrm{N}, \mathrm{P}$, and $\mathrm{K}$ is forecasted to increase at an average rate of about $2.5 \%$ per year to 2020 [11]. Since phosphate reserves are limited [12], there is a need to ensure that phosphorus is recycled to a large extent so that the rate of depletion of phosphate rock is reduced $[10,13]$. Dawson and Hilton [10] argued that legislation concerning management of phosphorus in agriculture appears entirely linked to its potential to disturb natural ecosystems with apparently no regulations yet requiring the efficient use and reuse of a finite resource.

In recent years, there has been a progressive increase in the price of mineral fertilisers [11]. This trend is likely to continue driven by the projected increase in fertiliser demand and the cost of energy with special regard to synthetic nitrogen fertilisers [11]. Enhanced quality of organic-based fertiliser materials can provide an opportunity to improve crop profit margins by means of reduced input costs of fertilisers while delivering some of the environmental benefits associated with recycling.

Development of new fertiliser products requires determining key properties of the materials that affect storage and spreading, soil behavior, and agronomic efficiency. The information available describing physical characteristics of organomineral fertiliser products is limited (e.g., $[9,14,15])$, which responds to the lack of legal requirements for their declaration on the label [16]. Conversely, the physical properties of mineral fertilisers have been studied in detail (e.g., $[17,18])$. Miller [18] indicated that fertiliser materials which have moderately high crushing strength can resist handling, storage, and spreading without significant shattering, dust formation, or caking. Density properties are related to the volume needed for storage and transport, and are required to calibrate fertiliser spreading equipment $[9,18]$. Particle size and size distribution affect uniformity of distribution during field application [19], and it is well documented that uneven spreading of fertilisers can increase nutrient losses to the environment, reduce fertiliser use efficiency and crop profit margins [20].

1.2. Organomineral Fertilisers. The literature abounds with reported experiences in the use of organomineral fertilisers applied to a variety of crops with satisfactory agronomic performances. According to the Working Groups drafting the revised EU Fertiliser Regulations EC2003/2003, organomineral fertiliser is defined as a fertiliser obtained by blending, chemical reaction, granulation, or dissolution in water of inorganic fertilisers having a declarable content of one or more primary nutrients with organic fertilisers or soil improver [21]. These products have been derived from a range of different organic and inorganic sources (e.g., [22-25]). Zebarth et al. [26] proposed the use of organic-based fertiliser materials to mitigate potential environmental effects associated with the use of mineral fertilisers alone which usually release their nutrients more rapidly following soil application. In such materials, the organic fraction protects the inorganic components by means of binding and absorption, thereby slowing the rate of release of plant nutrients [27]. Tejada et al. [28], however, suggested that the existence of a time lag between soil application and nutrients uptake by the crop can increase the risk of nutrient losses to the environment.

In the UK, some wastewater companies commercialise treated biosolids pellets available in one tonne bags for agricultural use, but they are produced without the addition of mineral fertilisers [29]. This article focuses on the study of physical and chemical characteristics of organomineral fertilisers which are produced by coating biosolids granules with urea and potash. A patent application (US7504035-B2) was assigned to United Utilities Group PLC [30] for the treatment of putrescible cakes for reduction of Escherichia coli and odour both of which are required in this product for safe spreading on agricultural land. The use of biosolids-derived organomineral fertilisers can reduce the cost of spreading by about 30\% compared with biosolids when these are applied at the optimum $\mathrm{N}$ rate in winter cereal crops [6]. Cost savings and differences in working rates become greater when compared with liquid sludges requiring injection [6].

The main aim of this development was to design a product that could satisfy the requirements of modern agricultural practices, maximise the use of biosolids in crop production, particularly, in areas close to production sites, and ultimately, reduce the reliance on mineral fertilisers. The GB Fertiliser Regulations are currently considering renewable sources of phosphorus, but discussions are still in their infancy. The use of biosolids-based organomineral fertilisers addresses an important issue of nutrient cycling between urban and agricultural ecosystems. The use of such products represents a technological advancement compared with ways that sewage sludge has been traditionally recycled in agriculture, and it appears to be in line with the current environmental and regulatory frameworks. The specific objective of this study was to characterise chemical and physical properties required to meet the specifications for organomineral fertilisers (OMFs) derived from nutrient-enriched biosolids granules for application in grassland and arable crops.

\section{Materials and Methods}

2.1. Description of the Products. The organomineral fertilisers (OMFs) are produced by drying digested sewage sludge cake $\left(25 \%\right.$ dry solids) at $80^{\circ} \mathrm{C}$ in a tumble dryer which produces granules of varying diameter and increases the dry solids content of the sludge to about $80 \%$ to $85 \%$. The sludge cake is produced at United Utilities Group PLC wastewater treatment works in Ellesmere Port in the NW 


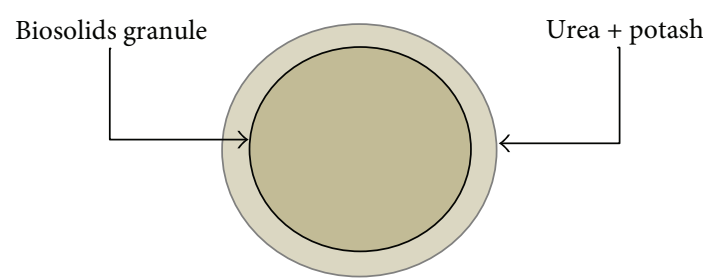

FIGURE 1: Schematic drawing of an organomineral fertiliser (OMF) particle.

of England. The sludge granules are subsequently coated, by means of spraying, with melted urea $(46 \% \mathrm{~N})$ and ground potash $\left(60 \% \mathrm{~K}_{2} \mathrm{O}\right)$ to raise the concentration of nitrogen and potassium, respectively. The final product is a compound NPK organomineral fertiliser which is shown in Figure 1. The core of the granules (biosolids) releases nutrients more slowly compared with the mineral fraction (urea and potash) [31].

The land application of sewage sludge (biosolids) is regulated by the Sludge (Use in Agriculture) Regulations 1989 S.I. no. 1263 which implements the provisions of the EU Sewage Sludge Directive 86/278/EEC [32] in Great Britain regarding the protection of the environment. The treatment of sewage sludge (biosolids) is a requirement prior to land application [33]. A process known as high rate enzyme hydrolysis is employed to control the pathogens load in biosolids [34]. This process takes place during the anaerobic digestion and it provides up to $99.9999 \%$ pathogens destruction [34] enabling compliance with the Safe Sludge Matrix [33].

2.2. Product Formulation. The organomineral fertiliser (OMF) products were suggested for broadcast application in grassland as well as arable cropping. Phosphorus fertilisation in excess of crop requirements may be avoided in soils that have satisfactory soil $\mathrm{P}$ Indexes as defined in [35]. Research [36] has shown that about $20 \%$ of the soils in Northern England had soil P Index 3 or greater (Olsen's P $\geq 45 \mathrm{mg} \mathrm{L}^{-1}$ ) which agrees with more recent information supplied by wastewater operators in the NW region of England [37]. High soil $\mathrm{P}$ status imposes a restriction to biosolids recycling, and it compromises meeting recycling targets by wastewater companies. It also increases the cost of disposal as biosolids require transportation farther away from wastewater treatment works.

Chemical analyses conducted on samples of biosolids granules [37] reported an average content of 3\% N (standard deviation $=0.81), 4.35 \% \mathrm{P}_{2} \mathrm{O}_{5}$ (standard deviation $\left.=1.07\right)$, and $0.15 \% \mathrm{~K}_{2} \mathrm{O}$ (standard deviation $=0.062$ ). The relatively low content of nitrogen compared to phosphorus results in low $\mathrm{N}: \mathrm{P}_{2} \mathrm{O}_{5}$ ratios which are often less than 1 . This can lead to a progressive build-up in soil $\mathrm{P}$ levels if biosolids are regularly applied based on crop nitrogen requirements. Soil P levels above the target Index [35] for the soil and crop system can have undesirable effects if $\mathrm{P}$ is subsequently lost to the environment [38]. This required increasing existing $\mathrm{N}: \mathrm{P}_{2} \mathrm{O}_{5}$ ratio in the base biosolids to (1) ensure that both nutrients were supplied to the crop in sufficient quantities for a grain yield of $8 \mathrm{tha}^{-1}$ considered to be typical of winter wheat crops in England [35] and (2) reduce the risk of increasing soil $\mathrm{P}$ Index when the fertilisation strategy considered routine application of OMF.

Narrow $\mathrm{N}: \mathrm{P}_{2} \mathrm{O}_{5}$ ratios in the product would be suitable for lower P Index soils; for example, less than 3, allowing for corrections to be made overtime towards the target Index [35]. Wider $\mathrm{N}: \mathrm{P}_{2} \mathrm{O}_{5}$ ratios suit situations where soil $\mathrm{P}$ Index is higher but where the overall fertility status of the soil is to be maintained. This requires that $\mathrm{P}$ fertilisation does not exceed but instead replenishes $\mathrm{P}$ offtake by crops. Based on this criterion, the content of phosphorus in OMF remained equivalent to that of the base biosolids granules. Nitrogen concentrations in OMF above the suggested $15 \%$ are technically possible, but this has some drawbacks. Firstly, it increases the manufacturing costs due to higher input cost of urea-N. Secondly, the production of more concentrated N products can reduce the total amount of biosolids recycled through agriculture. Equally, if the nitrogen concentration in the product was increased, the land bank for recycling would need to be increased accordingly to meet the same disposal targets compared with biosolids. Estimates [6] suggested that the required land bank for $\mathrm{OMF}_{15}$ would need to be approximately 1.5 times greater than that of $\mathrm{OMF}_{10}$ assuming that OMF-N was applied at a standard rate of $200 \mathrm{~kg} \mathrm{ha}^{-1}$ and that the price of nitrogen was equivalent to that of urea-N.

For winter wheat crops in soils with $\mathrm{P}$ Index below 3 , the recommended phosphorus application rates (grain yield: $8 \mathrm{tha}^{-1}$ ) are between 60 and $85 \mathrm{kgha}^{-1}$ of $\mathrm{P}_{2} \mathrm{O}_{5}$ [35]. Supplying these rates of phosphorus with biosolids would require between 1400 and $1950 \mathrm{~kg}$ of biosolids per hectare resulting in $\mathrm{N}$ application rates in the range of 140 to $160 \mathrm{~kg} \mathrm{ha}^{-1}$ based on the nutrients concentrations of biosolids mentioned earlier [37]. For a standard rate of $200 \mathrm{~kg} \mathrm{ha}^{-1}$ of $\mathrm{N}$ [35], the concentration of $\mathrm{N}$ in the biosolids, in percentage terms, should be increased from $3 \%$ to about $10 \%$ and $15 \%$, respectively. For potassium, the application of the same amount of biosolids would supply approximately 45 to $65 \mathrm{~kg} \mathrm{ha}^{-1}$ of $\mathrm{K}_{2} \mathrm{O}$ less than the recommended quantities for soils with $\mathrm{K}$ Index below 3 [35]. Hence, the concentration of potash in biosolids would need to be increased from $0.15 \%$ to about $3.5 \%$. From this simple analysis, the formulations of the two OMF products were inferred and the final compositions were approximated to $\mathrm{N}: \mathrm{P}_{2} \mathrm{O}_{5}: \mathrm{K}_{2} \mathrm{O}$ ratios: $15: 4: 4\left(\mathrm{OMF}_{15}\right)$ and $10: 4: 4\left(\mathrm{OMF}_{10}\right)$.

The application of $\mathrm{OMF}_{10}$ or $\mathrm{OMF}_{15}$ is not restricted to soils with P Indexes below 3; however, crop requirements for $\mathrm{P}$ should not be exceeded in soils which are above the target soil P Index. This criterion for P fertilisation is supported by the basic principle for $\mathrm{P}$ and $\mathrm{K}$ management which is to ensure the maintenance of sufficient nutrient reserves in the soil [39]. The narrower $\mathrm{N}: \mathrm{P}_{2} \mathrm{O}_{5}$ ratio of $\mathrm{OMF}_{10}$ compared with $\mathrm{OMF}_{15}$ makes it more suitable for situations with relatively lower soil P Index and vice versa with $\mathrm{OMF}_{15}$. Mixtures of these materials with other compatible fertiliser sources [40] may be used to match specific soil-crop requirements, but differences in their physical properties must be observed. A distinctive aspect of this product development is that the coating technology used to supplement biosolids 
with mineral fertilisers enables overcoming the expected variability in the chemical composition of sludges [41] to provide a consistent product.

2.3. Chemical Composition. Chemical analyses were conducted in compliance with the specifications outlined in the Fertilisers (Sampling and Analysis) Regulations 1991 S.I. no. 973. Total N was determined based on the Dumas technique [42] which converts the $\mathrm{N}$ present in the fertiliser sample to $\mathrm{N}_{x}$ gases and gaseous- $\mathrm{N}$ by means of combustion. The combustion products are subsequently converted to $\mathrm{N}_{2}$ and quantified by a Thermal Conductivity Detector (TCD). Total $\mathrm{P}\left(\% \mathrm{P}_{2} \mathrm{O}_{5}, \mathrm{w} \mathrm{w}^{-1}\right)$, total $\mathrm{K}\left(\% \mathrm{~K}_{2} \mathrm{O}, \mathrm{w} \mathrm{w}^{-1}\right)$, and heavy metals, total cadmium (Cd, $\left.\mathrm{mg} \mathrm{kg}^{-1}\right)$, total copper $\left(\mathrm{Cu}, \mathrm{mg} \mathrm{kg}^{-1}\right)$ and total zinc $\left(\mathrm{Zn}, \mathrm{mg} \mathrm{kg}^{-1}\right)$, were determined by means of digestion in concentrated hydrochloric and nitric acids (collectively known as aqua regia) in a microwave unit following the specifications given in $[43,44]$. The resulting solution was diluted volumetrically, and the total $\mathrm{Cd}, \mathrm{Cu}$, and $\mathrm{Zn}$ in the solution were subsequently determined by Atomic Absorption Spectrophotometer (AAS). The P content was determined by measuring the intensity of methylene blue colour formed using a spectrophotometer at $880 \mathrm{~nm}$. Cd was determined due to risk of plant toxicity at low concentrations and potential transfer to the food chain [45]. $\mathrm{Cu}$ and $\mathrm{Zn}$ are essential elements but can be toxic to plants and microorganisms above certain levels; therefore, maximum permissible levels in soil must be observed [46]. Soluble $\mathrm{P}\left(\% \mathrm{P}_{2} \mathrm{O}_{5}\right.$, $\mathrm{w} \mathrm{w}^{-1}$ ) was determined based on [43] to provide an indication of the fraction readily available for plant uptake. A sample was treated with $0.5 \mathrm{~mol} \mathrm{~L}^{-1}$ sodium hydrogen carbonate solution at $\mathrm{pH}$ 8.5. The extract was subsequently analysed using a spectrophotometer as explained above. Whilst the final method of detecting $\mathrm{P}$ is similar, the difference is in the extraction solution, that is, aqua regia and sodium hydrogen carbonate extract representing a more vigorous extract to denote total $\mathrm{P}$ and a more gentle extract to denote the plant available fraction, respectively.

2.4. Physical Properties. Particle size analysis was conducted by sieving samples of the fertiliser materials following the specifications outlined in [47]. Fertiliser samples of $500 \mathrm{~g}$ were passed through a series of sieves with apertures in the range of 0.60 to $37 \mathrm{~mm}$. The sieves were placed on a shaker for three minutes, and the fertiliser retained was weighed and expressed as percentage of the total weight of the sample. From the particle size analysis, the mean diameter $(d)$ was obtained. Standard BS EN 1235 [47] also recommends the characterisation of fertiliser materials by providing the values of percentiles $d_{16}, d_{50}$, and $d_{84}$. These correspond to particle diameters $(\mathrm{mm})$ below which $16 \%, 50 \%$, and $84 \%$ (by weight) of the material respectively can be collected after sieving [48]. The $d_{50}$ value equates to the median particle diameter [49]. Based on these percentiles, a granulometric spread index (GSI, \%) was derived [49]

$$
\mathrm{GSI}=\frac{d_{84}-d_{16}}{2 \times d_{50}} \times 100 .
$$

The GSI was used to provide an indication of the likelihood of the materials to undergo segregation during transport, handling, loading, and spreading. Segregation is the rearrangement of particles as a result of differences in their physical characteristics, particularly, the size ratio of particles [50]. The GSI is more commonly used to characterise blended than complex and compound fertilisers; however, its application to this situation is justified given the relatively wide range of particle sizes encountered in the samples. Based on [9], a uniformity index $\left(U_{i}, \%\right)$ was calculated which is the ratio times 100 of the two extreme sizes in the range of particles retained at the $95 \%\left(d_{95}\right)$ and at the $10 \%\left(d_{10}\right)$ levels, respectively [51]. A larger $U_{i}$ value indicates a more uniform granulometric distribution and vice versa.

Untapped bulk density $\left(\rho_{b} ; \mathrm{kg} \mathrm{m}^{-3}\right)$ was determined based on [52] by pouring of a fertiliser sample from a funnel into a measuring cylinder of known volume and weighing the contents and the cylinder. Particle density $\left(\rho_{p} ; \mathrm{kg} \mathrm{m}^{-3}\right)$ was determined by measuring the diameter and calculating the volume of individual fertiliser particles from a sample containing 100 particles and by recording the mass of the particles individually. Particle diameter was measured using a digital vernier calliper in two perpendicular directions to better account for unevenness in the particles' shape. Subsequently, the mean of the two measured diameters was obtained, which was the value used to calculate the volume of the particles; these were regarded as spherical. The porosity of untapped granules $\left(\eta ; \mathrm{m}^{3} \mathrm{~m}^{-3}\right)$ was calculated based on [9]:

$$
\eta=1-\frac{\rho_{b}}{\rho_{p}} .
$$

Static particle strength $\left(\tau ; \mathrm{N} \mathrm{mm}^{-2}\right)$ was determined using an Instron 1122 apparatus [53], previously calibrated [6], which consists of a frame and a moving crosshead. Particles were placed individually between the crosshead and the bottom of the frame. The crosshead (tip rod $=1 \mathrm{~mm}^{2}$ ) moved downwards at a speed of $95 \mathrm{~mm} \mathrm{~min}^{-1}$. The device has a load cell that senses the vertical load applied to the particle, and it was connected to a laptop computer which recorded the force applied versus the time. The force required to induce the breaking of the particle [17] or its complete compression, as determined by visual assessment, was recorded. For known crosshead speed, the vertical load versus time plot was converted to vertical load versus displacement [54]. Measurements were conducted for a selected range of particle diameters (from 2.85 to $6.30 \mathrm{~mm}$; except for urea: from 2.85 to $4.75 \mathrm{~mm})$. The total surface area per unit mass $\left(A ; \mathrm{m}^{2} \mathrm{~kg}^{-1}\right)$ of a fertiliser sample was estimated from the particle size analyses based on [55]

$$
A=\left(\frac{\beta_{s} W_{t}}{\beta_{v} \rho_{p}}\right) \exp \left[4.5 \times S_{\ln }^{2}-\ln d_{\mathrm{gw}}\right],
$$

where $\beta_{s}(\approx \pi)$ and $\beta_{v}(\approx \pi / 6)$ are the shape factors for calculating surface area and volume of particles, respectively, $\rho_{p}$ is the particle density $\left(\mathrm{g} \mathrm{cm}^{-3}\right), S_{\ln }\left(\approx 2.3 \log \left[d_{50} / d_{16}\right]\right)$ is the log-normal geometric standard deviation by mass in natural logarithm, $d_{\mathrm{gw}}\left(\approx d_{50}\right)$ is the geometric mean particle diameter $(\mathrm{cm})$, and $W_{t}$ is the mass of the sample $(\mathrm{g})$. 
TABLE 1: Chemical analyses conducted on $\mathrm{OMF}_{15}, \mathrm{OMF}_{10}$, and biosolids granules.

\begin{tabular}{lcccc}
\hline $\begin{array}{l}\text { Fertiliser material } \\
\text { Determination }\end{array}$ & $n$ & $\mathrm{OMF}_{15}$ & $\begin{array}{c}\mathrm{OMF}_{10} \\
\text { Mean } \pm \mathrm{SD}\end{array}$ & Biosolids granules \\
\hline Total $\mathrm{N}\left(\%, \mathrm{w} \mathrm{w}^{-1}\right)$ & 4 & $13.0 \pm 2.75$ & $9.0 \pm 1.55$ & $4.5 \pm 0.73$ \\
Total $\mathrm{P}_{2} \mathrm{O}_{5}\left(\%, \mathrm{w} \mathrm{w}^{-1}\right)$ & 4 & $3.8 \pm 0.23$ & $4.3 \pm 0.52$ & $5.5 \pm 0.97$ \\
Total $\mathrm{K}_{2} \mathrm{O}\left(\%, \mathrm{w} \mathrm{w}^{-1}\right)$ & 4 & $3.2 \pm 0.92$ & $3.0 \pm 0.61$ & $0.2 \pm 0.07$ \\
Total Cd $\left(\mathrm{mg} \mathrm{kg}^{-1} \mathrm{DS}\right)$ & 3 & $0.98 \pm 0.07$ & $0.98 \pm 0.15$ & $1.20 \pm 0.03$ \\
Total $\mathrm{Cu}\left(\mathrm{mg} \mathrm{kg}^{-1} \mathrm{DS}\right)$ & 3 & $268.4 \pm 10.7$ & $264.2 \pm 11.0$ & $329.3 \pm 11.6$ \\
Total $\mathrm{Zn}\left(\mathrm{mg} \mathrm{kg}^{-1} \mathrm{DS}\right)$ & 3 & $422.7 \pm 3.8$ & $422.2 \pm 5.6$ & $493.0 \pm 5.1$ \\
Soluble $\mathrm{P}\left(\%, \mathrm{w} \mathrm{w}^{-1}\right)$ & 3 & $<0.10 \pm 0.02$ & $<0.10 \pm 0.02$ & $0.20 \pm 0.05$ \\
$\mathrm{~N}: \mathrm{P}_{2} \mathrm{O}_{5}$ ratio & 4 & $3.4 \pm 0.75$ & $2.1 \pm 0.41$ & $0.80 \pm 0.29$ \\
\hline
\end{tabular}

(The standard deviation (SD) is shown as \pm the mean value; DS is dry solids).

2.5. Statistical Analyses. Statistical analyses were undertaken using GenStat 14th Edition [56]. For density properties, untapped porosity and particle strength analyses involved ANOVA and least significant differences to compare the means with a probability level of 5\% (LSD 5\% level). For particle size distribution, analyses involved $t$-tests $(95 \%$ confidence level) to compare the mean particle size and $F$ tests $(\alpha=0.05 ; 100$ degrees of freedom) to compare the variation in the particle size distribution between fertilisers. $F$-tests used a critical F-value of 1.41 [57].

\section{Results}

3.1. Chemical Composition. The results of the chemical analyses conducted on OMF and biosolids samples are summarised in Table 1.

Figure 2 shows a sample of $\mathrm{OMF}_{15}$ produced after coating biosolids granules with urea and potash.

Heavy metals ( $\mathrm{Cd}, \mathrm{Cu}$, and $\mathrm{Zn}$ ) content were below the recommended limit values given in the EC Sewage Sludge Directive 86/278/EEC [32] and therefore in compliance with the Sludge (Use in Agriculture) Regulations 1989 S.I. no. 1263. The Directive suggests the following limit values for heavy metals concentration in sludges intended for use in agriculture: 20 to $40 \mathrm{mg} \mathrm{kg}^{-1} \mathrm{DS}$ (Cd), 1000 to $1750 \mathrm{mg} \mathrm{kg}^{-1}$ DS $(\mathrm{Cu})$, and 2500 to $4000 \mathrm{mg} \mathrm{kg}^{-1} \mathrm{DS}(\mathrm{Zn})$, [32]. The relatively low concentration of soluble $\mathrm{P}$ confirmed that the majority of OMF-P and biosolids-P is not readily available for plant uptake. This responds to the technique used for the removal of $\mathrm{P}$ during the wastewater treatment process which is conducted by precipitation with $\mathrm{FeCl}_{3}$ resulting in the formation of Fe-phosphates. These compounds are largely unavailable for plant uptake following soil application [31]. The phosphorus thereby removed is subsequently incorporated into the sludge [58].

3.2. Physical Properties. The results of the measured physical properties are summarised in Table 2. The particle size and size distribution of $\mathrm{OMF}$ and biosolids granules varied between samples due to difficulties encountered during the coating process. Loss of heat occurred during the spraying of melted urea which meant that urea droplets solidified before being attached to the biosolids granules producing

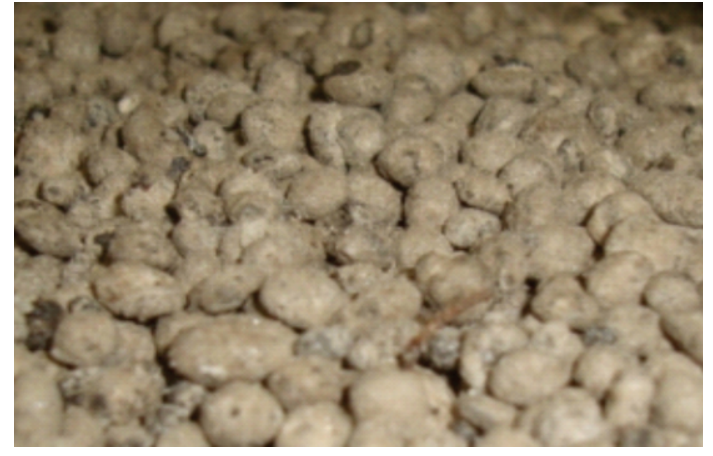

Figure 2: A sample of $\mathrm{OMF}_{15}$ with particles in the range of 1.18 to $5.50 \mathrm{~mm}$ in diameter.

unbounded urea (fine particles). Due to the relatively high temperatures used in the process (range of $120^{\circ}$ to $130^{\circ} \mathrm{C}$ ), fine particles of urea remelted and aggregated to biosolids granules. As a result, the thickness of the coating was not uniform for all granules which resulted in a relatively wide range of particle sizes. Particles ranged between $<0.60 \mathrm{~mm}$ (up to $3 \%$ and $6 \%$ in $\mathrm{OMF}_{10}$ and $\mathrm{OMF}_{15}$, resp.) and $25 \mathrm{~mm}$ (up to $5 \%$ and $2 \%$ in $\mathrm{OMF}_{10}$ and $\mathrm{OMF}_{15}$, resp.) in diameter. The two OMF products did not show significant differences in the mean particle diameters, but these were significantly higher $(t$-values $>1.96)$ compared with biosolids granules and urea. The $F$-tests indicated significant differences $(F$-values $>$ 1.41) between the two OMF products compared with urea for all fertiliser samples.

Overall, there were significant differences in bulk density depending on the fertiliser type $(P=0.024)$. This effect was mainly due to the value encountered for urea which was on average $20 \%$ to $30 \%$ higher compared with the other fertiliser materials. The measured bulk densities of biosolids granules, $\mathrm{OMF}_{10}$, and $\mathrm{OMF}_{15}$ were not significantly different for an LSD value (5\% level) of $110 \mathrm{~kg} \mathrm{~m}^{-3}$. There were significant differences $(P=0.002)$ in particle densities, but the overall effect was due to urea which was on average $6 \%$ to $10 \%$ higher compared with the other materials. Similarly, biosolids granules, $\mathrm{OMF}_{10}$, and $\mathrm{OMF}_{15}$ were not significantly different in their particle densities for an LSD value (5\% level) of $73 \mathrm{~kg} \mathrm{~m}^{-3}$. 
TABLE 2: Physical properties determined on $\mathrm{OMF}_{15}, \mathrm{OMF}_{10}$, biosolids granules, and urea.

\begin{tabular}{|c|c|c|c|c|c|c|}
\hline $\begin{array}{l}\text { Fertiliser material } \\
\text { Physical property }\end{array}$ & $n$ & $\mathrm{OMF}_{15}$ & $\begin{array}{l}\mathrm{OMF}_{10} \\
\text { Mean } \pm \mathrm{SD}\end{array}$ & Biosolids granules & $n$ & $\begin{array}{c}\text { Urea } \\
\text { Mean (or value) } \pm \text { SD }\end{array}$ \\
\hline$d_{16}(\mathrm{~mm})$ & 4 & $2.52 \pm 1.0$ & $2.40 \pm 0.6$ & $2.74 \pm 3.1$ & 1 & 2.52 \\
\hline$d_{50}(\mathrm{~mm})$ & 4 & $4.60 \pm 2.8$ & $4.45 \pm 2.8$ & $4.87 \pm 5.6$ & 1 & 3.03 \\
\hline$d_{84}(\mathrm{~mm})$ & 4 & $7.24 \pm 4.4$ & $6.91 \pm 5.2$ & $7.08 \pm 7.5$ & 1 & 3.73 \\
\hline$d(\mathrm{~mm})$ & $\infty$ & $5.42 \pm 2.6$ & $5.28 \pm 2.9$ & $4.97 \pm 5.5$ & $\infty$ & $3.10 \pm 0.35$ \\
\hline GSI (\%) & 4 & $49.3 \pm 14.3$ & $43.6 \pm 16.1$ & $48.9 \pm 7.7$ & 1 & 20.0 \\
\hline$A\left(\mathrm{~m}^{2} \mathrm{~kg}\right)$ & 4 & $20.9 \pm 32.2$ & $13.6 \pm 21.2$ & $7.0 \pm 5.1$ & 1 & 1.61 \\
\hline$U_{i}(\%)$ & 4 & $15.7 \pm 9.6$ & $22.7 \pm 16.2$ & $24.7 \pm 4.8$ & 1 & 57.3 \\
\hline$\rho_{b}\left(\mathrm{~kg} \mathrm{~m}^{-3}\right)$ & 4 & $603 \pm 73.1$ & $623 \pm 85.5$ & $578 \pm 87.2$ & 3 & $748 \pm 5.7$ \\
\hline$\rho_{p}\left(\mathrm{~kg} \mathrm{~m}^{-3}\right)$ & 100 & $1357 \pm 178$ & $1297 \pm 263$ & $1333 \pm 315$ & 100 & $1432 \pm 255$ \\
\hline$\eta\left(\mathrm{m}^{3} \mathrm{~m}^{-3}\right)$ & 4 & $0.56 \pm 0.05$ & $0.52 \pm 0.07$ & $0.57 \pm 0.07$ & 3 & $0.48 \pm 0.01$ \\
\hline${ }^{\mathrm{a}} \tau\left(N \mathrm{~mm}^{-2}\right)$ & 2 & $4.10 \pm 0.11$ & $4.33 \pm 0.08$ & $5.85 \pm 0.26$ & 2 & $4.25 \pm 0.06$ \\
\hline${ }^{\mathrm{b}} \tau\left(N \mathrm{~mm}^{-2}\right)$ & 2 & $2.85 \pm 0.09$ & $2.78 \pm 0.11$ & $1.64 \pm 0.04$ & 2 & $3.11 \pm 0.05$ \\
\hline${ }^{\mathrm{c}} \tau\left(N \mathrm{~mm}^{-2}\right)$ & 2 & $2.14 \pm 0.23$ & $2.12 \pm 0.14$ & $2.24 \pm 0.34$ & 2 & $1.38 \pm 0.02$ \\
\hline${ }^{\mathrm{d}} \tau\left(N \mathrm{~mm}^{-2}\right)$ & 2 & $1.25 \pm 0.04$ & $1.18 \pm 0.06$ & $1.23 \pm 0.02$ & - & - \\
\hline
\end{tabular}

(For $\tau$, particle size ranges were: ${ }^{\mathrm{a}} 2.00-3.35 \mathrm{~mm} ;{ }^{\mathrm{b}} 3.35-4.00 \mathrm{~mm} ;{ }^{\mathrm{c}} 4.00-5.50 \mathrm{~mm} ;{ }^{\mathrm{d}} 5.50-7.10 \mathrm{~mm}$. For urea, particles in the sample were smaller than $5.50 \mathrm{~mm}$ in diameter; therefore, $\tau$ is not shown for the range of 5.50 to $7.10 \mathrm{~mm}$. The standard deviation (SD) is shown as \pm the mean value, except for $n=1$ ).

The calculated values of porosity were not significantly different $(P=0.14)$, but the difference between urea and biosolids granules appears to be significant for an LSD value $\left(5 \%\right.$ level) of $0.08 \mathrm{~m}^{3} \mathrm{~m}^{-3}$. The relatively lower value of porosity in urea samples was expected given that $\eta$ was calculated from density properties [9]. Allaire and Parent [16] encountered higher total porosity values in materials with more organic matter content which explains the relatively higher value of $\eta$ in biosolids compared with the two OMF products.

The surface area of urea was significantly lower compared to the other fertiliser materials which was due to the relatively lower proportion of fine particles $(<1.18 \mathrm{~mm})$ in the sample, and the same holds true when comparing $\mathrm{OMF}_{10}$ and $\mathrm{OMF}_{15}$. Compression tests showed that OMF and biosolids granules undergo deformation followed by multiple fractures without disintegration of the granule when vertical load was applied (Figure 3).

Unlike urea particles, OMF and biosolids granules behaved in a plastic fashion and did not show a characteristic force that induced the breaking of the particle. Deformation started immediately after the tip rod made contact with the granule and the test was allowed to progress until the particles were fully compressed, as recorded by visual assessment. As a result, for OMF and biosolids, the value of $\tau$ reported in Table 2 was obtained by dividing the force required to induce full compression of the particle by its cross-sectional area. Depending on the fertiliser material and the particle diameter, full compression was observed when the vertical load applied was approximately in the range of 18 to $44 \mathrm{~N}$. This response of the materials was attributed to the moisture content (range of $10.7 \%$ to $17.3 \% \mathrm{w} \mathrm{w}^{-1}$ ) and their organic nature. Figure 4 shows a vertical load versus displacement diagram for particles of urea and $\mathrm{OMF}_{10}$. It can be seen that the particle of urea breaks at $33 \mathrm{~N}$ whereas the $\mathrm{OMF}_{10}$ granule compresses to a further extent requiring a force of $29 \mathrm{~N}$ to
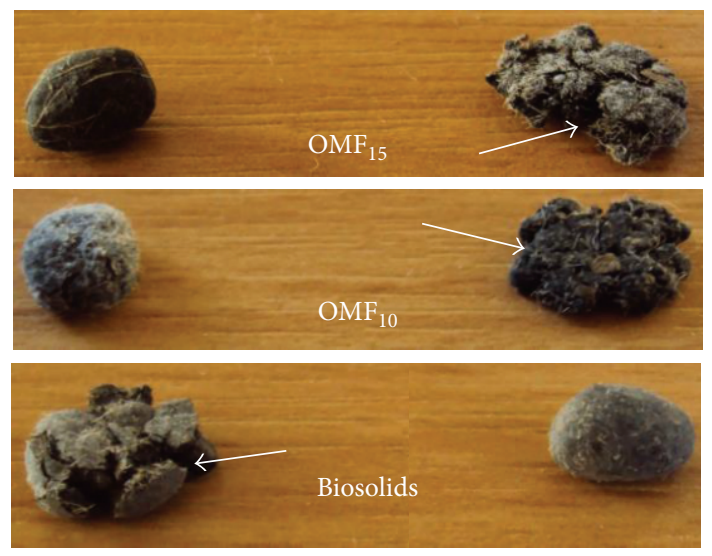

FIGURE 3: $\mathrm{OMF}_{15}, \mathrm{OMF}_{10}$ and biosolids granules (range of 3.35 to $4.00 \mathrm{~mm}$ ). The arrows show the multiple failures produced during the compression tests.

reach full compression, but displacement is approximately double.

Due to the behaviour exhibited by OMF and biosolids granules, the statistical analysis to determine differences in the breaking force was only conducted for particles of urea: particles in the range of 3.35 to $4.00 \mathrm{~mm}$ in diameter required a significantly $(P<0.001)$ higher force $(32.9 \mathrm{~N})$ compared with those in the range of 2.36 to $3.35 \mathrm{~mm}(23.8 \mathrm{~N})$ and 4.00 to $5.50 \mathrm{~mm}(24.4 \mathrm{~N})$, respectively, which were not statistically different for an LSD value (5\% level) of $1.26 \mathrm{~N}$.

\section{Discussion}

$\mathrm{OMF}_{10}$ and $\mathrm{OMF}_{15}$ were not strictly made to specification due to some challenges encountered during the coating 


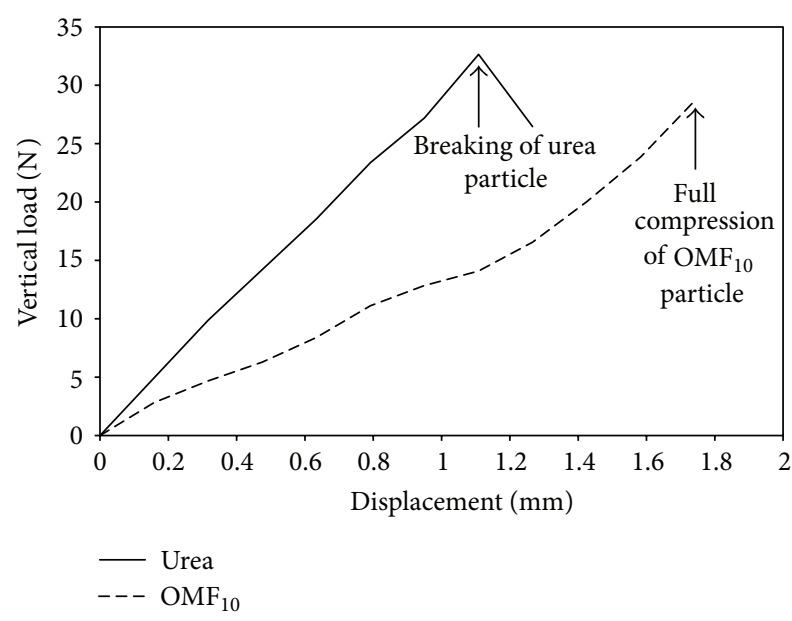

FIGURE 4: Vertical load versus displacement recorded in particles of urea and $\mathrm{OMF}_{10}$ (particle size range: 3.35 to $4.00 \mathrm{~mm}$ ).

process. On average, the concentrations of nitrogen, phosphate, and potash were slightly lower than the corresponding formulations. Consequently, a recommendation was made to correct nutrient shortfalls for soil application of OMF, so that it could meet the formulation specifications required for crop growth. The difficulties found during the coating process were related to heating urea and spraying it onto biosolids granules which causes urea to volatilise with subsequent loss of nitrogen, thereby affecting the amount added to the formulation. Optimisation of the coating technology involving suitable temperature ranges needs to be carried out to overcome this challenge.

The relatively greater surface area $(A)$ in the two OMF products compared with biosolids granules will enhance contact of particles with soil and soil water following field spreading as observed in the study of Allaire and Parent [16]. Given the relatively low degradability of the organic$\mathrm{N}$ fraction in OMF [31], increased surface area and particle contact with soil will favour the release of nutrients following application to a greater extent compared with biosolids granules. However, the increase in total surface area as result of increased proportion of small particles $(<1 \mathrm{~mm})$ should be avoided due to adverse effects upon spreader performance.

Miserque and Pirard [59] indicated that granulometric segregation in bulk blended fertilisers can be minimised at granulometric spread indexes (GSIs) of about $15 \%$ or lower while values above $25 \%$ will likely produce severe segregation. Segregation can occur with blends as well as complex and compound fertilisers which have relatively wide range of particle sizes [50]. For low-quality compound fertilisers whose particles do not have similar chemical composition, segregation results in uneven distribution of nutrients in the field [50]. When segregation occurs before loading the fertiliser spreader, the spreading width can be affected [60]. This is due to smaller and larger particles coming through in turns during loading and being subsequently delivered at different times during spreading [60]. As a result, the uniformity of distribution both longitudinally and transversely can be adversely affected $[17,60]$. For $\mathrm{OMF}_{10}$ and $\mathrm{OMF}_{15}$, it was found [6] that particle density decreases with increasing particle diameter $(P \leq 0.001)$ which will enhance segregation if the materials have a relatively wide particle size range.

On average, the percentage of fine particles $(<1.18 \mathrm{~mm})$ in the two OMF products accounted for about 4\% (by weight) across all fertiliser samples (range: $0.15 \%$ to $16.5 \%$ by weight). These particles must be maintained to a minimum since the fraction below $1 \mathrm{~mm}$ is greatly responsible for the increase in the coefficient of variation $(\mathrm{CV})$ during broadcast spreading [61]. The values of GSI reported by Miserque and Pirard [59] provide a valuable threshold to compare against those obtained for OMF. Given the relatively wide range of particle sizes encountered, it can be stated that particle segregation is therefore likely to occur affecting distribution uniformity during broadcast spreading.

The compression tests demonstrated that OMF and biosolids granules did not show a characteristics force that induced the fracture of the particles. Instead, OMF and biosolids granules deformed permanently when a relatively small force was applied and behaved in a plastic fashion. An important feature was that OMF and biosolids granules exhibited multiple failures and they did not disintegrate into smaller particles as it was observed with urea when the breaking force was reached. Studies with urea [62] showed that this force must be greater than approximately $15 \mathrm{~N}$ to avoid particle fracture during handling. At this equivalent force, $\mathrm{OMF}_{10}$ particles had been compressed to about $50 \%$ (Figure 4). Particle deformation influences the aerodynamic properties of the material as a result of changes in the particle shape. Miller [18] indicated that particle shape is related to spreader distribution and metering flow performances as it affects particle motion in the distributor. Since one of the reasons for the relatively low particle strength was the moisture content of the material, it is suggested that this should be maintained at about $10 \%\left(\mathrm{w} \mathrm{w}^{-1}\right)$. Lower values can significantly increase the cost of energy during the granulation process. The use of plastic packaging for OMF may be recommended to prevent increases in moisture content of the material. Urea particles exhibited breaking forces which are considered to be satisfactory as they were above the lower limit suggested by Hignett [62].

Fertilisers with wide range of particle sizes can suffer from caking due to increased number of contact points and relatively high bond strength per unit mass of the fertiliser [63]. Caking is likely to be enhanced when increased porosity and low particle strength are combined [63] which was observed in OMF and biosolids granules. An increase in the percentage of fine particles results in increased particle-contact area which combined with low particle strength can produce compaction of the material during storage. Allaire and Parent [16] highlighted that particle strength increases with density which agrees with the relatively higher density and strength encountered for particles of urea compared with OMF and biosolids granules. The values of porosity encountered in the two OMF products were relatively lower than those of OMF compounds reported by Paré et al. [9] but of similar magnitude to those obtained by Allaire and Parent [16] for bulk-blended and compound organic-based fertilisers. 
The mean values of bulk density for urea corresponded with those reported in the literature [63]; however, the two OMF products had relatively lower values compared with other compound organic-based fertilisers [16]. Fertiliser materials with low bulk density lead to increased cost of transport and spreading [16]. The relatively lower bulk density of biosolids compared with OMF is explained by higher organic matter in the former material compared with the latter.

Mixing of fertilisers may be restricted when differences in the size grade number between the materials are large [64]. Therefore, due to the relatively large differences in particle size, size distribution, and particle density encountered between OMF and urea (Table 2), the bulk mixture of the two fertiliser types may not be recommended. Based on the relationship between flow time and bulk density encountered by Miller [18] for straight $\mathrm{N}$ fertilisers and given the differences in density properties that exist between $\mathrm{OMF}$ and urea, a mixture of the two materials may result in significant differences in their flow time which will affect spreading uniformity.

Particle density for urea was within the range (from 1250 to $1500 \mathrm{~kg} \mathrm{~m}^{-3}$ ) reported in the literature $[65,66]$ which confirmed that the technique used for measuring particle density was adequate. For OMF, mean values of particle density were lower than those reported by Allaire and Parent [16] for bulk-blended and compound organicbased fertilisers (range of 1540 to $2270 \mathrm{~kg} \mathrm{~m}^{-3}$ ) but within the range (from 900 to $1580 \mathrm{~kg} \mathrm{~m}^{-3}$ ) of values encountered by Paré et al. [9]. Due to the relatively low particle density of OMF, field application with twin discs fertiliser spreaders at wide tramline spacing (e.g., greater than $18 \mathrm{~m}$ apart) may not possible. Given that OMF granules did not shatter during the compression tests conducted, it may be possible to set the disc of the fertiliser spreader at higher than standard rotational velocities, typically used with mineral fertilisers, to enable application of the material at greater spreading widths (e.g., at $24 \mathrm{~m}$ tramline spacing). However, because of greater forces exerted on the particles at higher rotational velocities, deformation of the granules can occur which can affect their aerodynamic properties.

Antille [6] reported satisfactory results from distribution uniformity and machinery calibration field tests conducted with OMF using a pneumatic fertiliser applicator Kuhn 2212. The pneumatic applicator performed well when delivering an application rate equivalent to $455 \mathrm{~kg} \mathrm{ha}^{-1}$ of OMF which was uniform both across the working width of the machine and along the tramline. The data reported by Antille [6] showed that there were no significant differences $(P=0.572)$ in the amount of fertiliser collected in three sets of nine trays (dimensions $0.5 \times 0.5 \times 0.15 \mathrm{~m}$ ) placed at $10 \mathrm{~m}$ intervals along the tramline. The author observed that the variation (CV $=12.4 \%)$ in the amount of fertiliser collected in the trays was mainly due to fine particles $(<1.18 \mathrm{~mm})$ which originated from disintegration of large aggregates of urea $(>5.50 \mathrm{~mm})$ in the hopper and in the boom during fertiliser application. Compression tests showed that these aggregates of urea, which originated during the coating process, break when a relatively small force (vertical load $=4.43 \mathrm{~N}$ ) is applied [6]. Despite this, the above results demonstrated the suitability of OMF for application with pneumatic applicators, but further work is required to determine whether this material can be uniformly applied with twin discs spreaders which are the common type in the UK.

In this respect, a model developed for fertiliser particle distribution studies $[6,67]$ showed that OMF particles should be between 1.10 and $5.50 \mathrm{~mm}$ in diameter with about $80 \%$ of the particles in the range of 2.25 to $4.40 \mathrm{~mm}$ to enable application with twin discs fertiliser spreaders at $18 \mathrm{~m}$ tramline spacing. This requires that particles leave the spinning disc with velocities in the range of 20 to $40 \mathrm{~m} \mathrm{~s}^{-1}$ for discs set at angles between $0^{\circ}$ and $10^{\circ}$ and at $1 \mathrm{~m}$ above the ground level. Therefore, the particle size and size distribution of the two OMF products reported in this study require optimisation to enable broadcast spreading at conventional tramline widths. Field spreading tests (e.g., ASAE [68]) will aid the optimisation of the physical properties of OMF and will verify the information obtained with the above model $[6,67]$.

\section{Conclusions}

(1) The proposed $\mathrm{OMF}_{15}$ and $\mathrm{OMF}_{10}$ formulations were based on relatively high $\mathrm{N}: \mathrm{P}_{2} \mathrm{O}_{5}$ ratios $(\geq 2.5)$ which will reduce the risk of build-up of soil $\mathrm{P}$ in areas near to sewage treatment works allowing for a wider range of land bank to receive organomineral fertilisers.

(2) The physical properties investigated showed that it may be possible to conduct field application of organomineral fertilisers with standard broadcast fertiliser spreading equipment at $18 \mathrm{~m}$ tramline spacing. However, this requires improving the quality control for the physical properties of the products with particular regard to particle size and size distribution which showed some variability in the samples analysed. The coating process of biosolids granules with urea requires optimisation to enable consistency in the product formulations.

(3) Optimisation of the particle size and size distribution are required for safe spreading on the land to minimise adverse effects on the environment, poor fertiliser use efficiency by crops, and loss of crop productivity. Initial efforts should be made to perfect $\mathrm{OMF}_{15}$ as this product has higher $\mathrm{N}$ content and it could better fit the needs of the market in the proximity of wastewater treatment works in the NW region of England.

(4) The conversion of biosolids into organomineral fertilisers addresses an important issue of nutrient cycling between urban and agricultural ecosystems. A key aspect of this product development is that it will contribute to maximising the use of biosolids in agriculture in areas that are close to production sites. The cost of disposal of sewage sludge can be significantly reduced while enabling wastewater companies meeting recycling targets and securing the 
agricultural route for disposal. Farmers may be able to reduce the reliance on mineral fertilisers, which are going up in price, and therefore reduce fertiliser input costs, while maintaining overall soil fertility.

\section{Acknowledgments}

This research received funding from the European Union Seventh Framework Programme (FP7-ENV.2010.3.1.1-2 ENV) under Grant agreement no. 265269 (http://www.endo-sludg.eu/). The article represents the opinion of the authors and does not necessarily represent the view of the European Union or United Utilities Group PLC. The authors are grateful to United Utilities Group PLC, The Engineering and Physical Science Research Council, and Cranfield University for financial and operational support to conduct this research. Help received from S. Whipp, Mr S. Gedara (United Utilities), and P. Bellamy and the staff at the Soil and Water Laboratory (Cranfield University) is appreciated.

\section{References}

[1] Department for Environment, Food, and Rural Affairs, Waste strategy for England 2007. PB12596, 2007, http://archive.defra .gov.uk/environment/waste/strategy/strategy07/documents/ waste07-strategy.pdf.

[2] F. Laturnus, K. von Arnold, and C. Grøn, "Organic contaminants from sewage sludge applied to agricultural soils false alarm regarding possible problems for food safety?" Environmental Science and Pollution Research, vol. 14, no. 1, pp. 53-60, 2007.

[3] S. R. Smith, The Implications For Human Health and Environment of Recycling of Biosolids Onto Agricultural Land, Centre for Environmental Control and Waste Management, Imperial College of London, London, UK, 2008.

[4] Council of the European Communities, "Council Directive 99/31/EC of 26 April 1999 on the landfill of waste," Official Journal of the European Communities L, vol. 182, pp. 1-19, 1999.

[5] Department for Environment, Food and Rural Affairs, "Landfill Directive: What are the Landfill Directive's aim and objectives?" 2007, http://archive.defra.gov.uk/environment/waste/strategy/ legislation/landfill/documents/landfilldir.pdf.

[6] D. L. Antille, Formulation, utilisation and evaluation of organomineral fertilisers [Engineering Doctorate Thesis], Cranfield University, Bedford, UK, 2011.

[7] D. Edge, "Perspectives for nutrient removal from sewage and implications for sludge strategy," Environmental Technology, vol. 20, no. 7, pp. 759-763, 1999.

[8] Royal Society of London, "Reaping the benefits: science and the sustainable intensification of agriculture," RS Policy Document 11/09, RS1608, London, UK, 2009, http://royalsociety.org/Reapingthebenefits/.

[9] M. C. Paré, S. E. Allaire, L. Khiari, and C. Nduwamungu, "Physical properties of organo-mineral fertilizers-Short Communication," Canadian Biosystems Engineering, vol. 51, no. 3, pp. 21-27, 2009.

[10] C. J. Dawson and J. Hilton, "Fertiliser availability in a resourcelimited world: production and recycling of nitrogen and phosphorus," Food Policy, vol. 36, no. 1, pp. 14-22, 2011.
[11] P. Heffer and M. Prud'homme, "Fertilizer outlook 2013-2017," in Proceedings of the 81st International Fertilizer Industry Association Conference, p. 8, Chicago, Ill, USA, May 2013, Paper No.: A/13/78, http://www.fertilizer.org/.

[12] J. R. Herring and R. J. Fantel, "Phosphate rock demand into the next century: impact on world food supply," Nonrenewable Resources, vol. 2, no. 3, pp. 226-246, 1993.

[13] H. P. Weikard and D. Seyhan, "Distribution of phosphorus resources between rich and poor countries: the effect of recycling," Ecological Economics, vol. 68, no. 6, pp. 1749-1755, 2009.

[14] S. E. Allaire and L. E. Parent, "Size guide number and rosinrammler approaches to describe particle size distribution of granular organic-based fertilisers," Biosystems Engineering, vol. 86, no. 4, pp. 503-509, 2003.

[15] S. E. Allaire and L. E. Parent, "Physical properties of granular organic-based fertilisers, part 2: dynamic properties related to water," Biosystems Engineering, vol. 87, no. 2, pp. 225-236, 2004.

[16] S. E. Allaire and L. E. Parent, "Physical properties of granular organic-based fertilisers, part 1: static properties," Biosystems Engineering, vol. 87, no. 1, pp. 79-87, 2004.

[17] J. W. Hofstee and W. Huisman, "Handling and spreading of fertilizers. Part 1: physical properties of fertilizer in relation to particle motion," Journal of Agricultural Engineering Research, vol. 47, pp. 213-234, 1990.

[18] P. C. H. Miller, The measurement and classification of the flow and spreading characteristics of individual fertilisers, Proceeding no. 390, The International Fertiliser Society, York, UK, 1996.

[19] J. W. Hofstee, Physical properties of fertilisers in relation to handling and spreading [Ph.D. Thesis], Department of Agricultural Engineering and Physics, Wageningen Agricultural University, Wageningen, The Netherlands, 1993.

[20] K. Dilz and G. D. van Brakel, Effects of Uneven Fertiliser Spreading-Part I: A Literature Review, Proceeding no. 240, The International Fertiliser Society, York, UK, 1985.

[21] Anon, "Minutes of Working Group 1-Overall structure of the future Fertiliser Regulations EC2003/2003," Brussels, Belgium, Meeting on June 2012.

[22] E. A. Makinde, "Effect of an organo-mineral fertilizer application on the growth and yield of maize," Journal of Applied Sciences Research, vol. 3, no. 10, pp. 1152-1155, 2007.

[23] World Intellectual Property Organization, (WO/2009/129589) Process for producing organo-mineral fertilizers, 2009, http:// www.wipo.int/pctdb/en/wo.jsp?WO=2009129589.

[24] M. C. Paré, S. E. Allaire, L. Khiari, and L. E. Parent, "Improving physical properties of organo-mineral fertilizers: Substitution of peat by pig slurry composts," Applied Engineering in Agriculture, vol. 26, no. 3, pp. 447-454, 2010.

[25] M. M. Rady, "A novel organo-mineral fertilizer can mitigate salinity stress effects for tomato production on reclaimed saline soil," South African Journal of Botany, vol. 81, pp. 8-14, 2012.

[26] B. J. Zebarth, R. Chabot, J. Coulombe, R. R. Simard, J. Douheret, and N. Tremblay, "Pelletized organo-mineral fertilizer product as a nitrogen source for potato production," Canadian Journal of Soil Science, vol. 85, no. 3, pp. 387-395, 2005.

[27] Food and Agricultural Organization of the United Nations, "Database on commercially available organic fertilizers and water-retaining products," Land and Water Development Division, 2007, http://www.fao.org/AG/aGL/agll/orgfert/intro.stm.

[28] M. Tejada, C. Benítez, and J. L. González, "Effects of application of two organomineral fertilizers on nutrient leaching losses and wheat crop," Agronomy Journal, vol. 97, no. 3, pp. 960-967, 2005. 
[29] S. Spence, "Bestway Fertilisers," Personal communication. Southern Water, Worthing, West Sussex, UK, 2010.

[30] United Utilities Group PLC, US Patent No.: US7504035 B2, 17 March 2009 for the treatment of putrescible cakes. Assignee: United Utilities PLC. Inventors: M.S. Le (UK) and N.T. Shatin (Hong Kong), 2009.

[31] D. L. Antille, R. Sakrabani, and R. J. Godwin, "Nitrogen and phosphorus availability following topsoil application of organomineral fertilisers," American Society of Agricultural and Biological Engineers, vol. 5, pp. 4134-4150, 2012.

[32] Council of European Communities, "Council Directive EU Sewage Sludge Directive 86/278/EEC of 12 June 1986 on the protection of the environment and the soil when sewage sludge is used in agriculture," Official Journal of the European Communities L, vol. 181, p. 6, 1986.

[33] ADAS, Guidelines for the Application of Sewage Sludge to Agricultural Land: the Safe Sludge Matrix, ADAS Gleadthorpe Research Centre, Mansfield, UK, 3rd edition, 2001.

[34] M. S. Le, T. Briddon, D. Harrison, and A. Werker, "Enzymic hydrolysis technology demonstration: production of enhanced treated biosolids for agricultural recycling," in Proceedings of the 11th European Biosolids and Organic Resources Conference. Aqua-Enviro Technology Transfer, Wakefield, UK, November 2006.

[35] Department for Environment, Food and Rural Affairs, Fertiliser Manual (RB209), The Stationery Office, London, UK, 8th edition, 2010.

[36] R. J. Skinner and A. D. Todd, "Twenty-five years of monitoring $\mathrm{pH}$ and nutrient status of soils in England and Wales," Soil Use and Management, vol. 14, no. 3, pp. 162-169, 1998.

[37] United Utilities Group PLC, "Chemical analyses of sewage sludge (biosolids)," Internal Report, United Utilities Group PLC, Warrington, UK, 2006.

[38] M. Alvarez-Cobelas, S. Sánchez-Carrilo, D. G. Angeler, and R. Sánchez-Andrés, "Phosphorus exports from catchments: a global view," Journal of the North American Benthological Society, vol. 28, no. 4, pp. 805-820, 2009.

[39] C. J. Dawson, "Phosphate and potash-reconsidering their importance and use," Journal of the Royal Agricultural Society of England, vol. 172, pp. 1-9, 2011.

[40] AFCOME, Association Française de Commercialisation et de Mélange d'Engrais, "Bulk blending manuel de qualité, lére partie," in Proceedings of the 14th International Meeting of the Association Française de Commercialisation et de Mélange d'Engrais (L'AFCOME '95), 1995, http://www.afcome.org/Accueil.html.

[41] L. E. Sommers, "Chemical composition of sewage sludges and analysis of their potential use as fertilizers," Journal of Environmental Quality, vol. 6, no. 2, pp. 225-232, 1977.

[42] J. B. A. Dumas, "Procédés de l’analyse organique," Annales des Chimie et des Physique, vol. 2, no. 47, pp. 198-213, 1831.

[43] Ministry of Agriculture, Fisheries and Food, The Analysis of Agricultural Materials (RB 427), The Stationery Office, London, UK, 3rd edition, 1986.

[44] British Standard 7755 Section 3.13, Soil Quality. Chemical Methods. Determination of Cadmium, Chromium, Cobalt, Copper, Lead, Manganese, Nickel and Zinc in Aqua Regia Extracts of Soil. Flame and Electrothermal Atomic Absorption Spectrometric Methods, The British Standards Institution, London, UK, 1998, Equivalent to ISO, 11047:1998.

[45] K. C. Jones and A. E. Johnston, "Cadmium in cereal grain and herbage from long-term experimental plots at Rothamsted, UK," Environmental Pollution, vol. 57, no. 3, pp. 199-216, 1989.
[46] Ministry of Agriculture, Fisheries, and Food, Code of Good Agricultural Practice For the Protection of Soil (Revised), The Stationery Office, London, UK, 1998.

[47] British Standard, Solid Fertilizers-Test Sieving [British-Adopted European Standard], The British Standards Institution, London, UK, 1995.

[48] K. Persson, Interaction between fertilisers and spreaders, Proceeding no. 389, The International Fertiliser Society, York, UK, 1996.

[49] O. Miserque, E. Pirard, Y. Schenkel, O. Mostade, and B. Huyghebaert, "Spreading segregation of blended fertilizers: influence of the particles properties," Applied Engineering in Agriculture, vol. 24, no. 2, pp. 137-144, 2008.

[50] I. A. Bridle, M. S. A. Bradley, A. R. Reed et al., Non-segregating blended fertiliser development: a new predictive test for optimising granulometry, Proceeding no. 547, The International Fertiliser Society, York, UK, 2004.

[51] Canadian Fertilizer Institute, Bulk Blend. Quality Control Manual, CFI, Ontario, Canada, 2001.

[52] British Standard, "Fertilizers-determination of bulk density (loose) [British-adopted European Standard equivalent to the modified version of ISO, 3944 (1992)]," The British Standards Institution, London, UK, 1995.

[53] Instron Corporation, Instron Model 1122 Universal Testing Instrument, "Operating instructions (Revised 1985)", Manual M10-1122-1(B), 1985.

[54] G. J. Gouw and H. W. Wevers, "Behaviour of an INSTRON 1122 under cyclic testing over a small displacement range," Journal of Biomedical Engineering, vol. 4, no. 1, pp. 72-74, 1982.

[55] American Society of Agricultural Engineers, Method of Determining and Expressing Fineness of Feed Materials by Sieving, ASAE, St. Joseph, Mich, USA, 2006, ANSI/ASAE-S.319.3 FEB03. ASAE Standards.

[56] GenStat Release 14.1, VSN International, Hemel Hempstead, UK, 14th edition, 2011.

[57] F. J. Rohlf and R. R. Sokal, Statistical Tables, W. H. Freeman, New York, NY, USA, 3rd edition, 1995.

[58] M. I. Kokkora, D. L. Antille, and S. F. Tyrrel, "Considerations for recycling of compost and biosolids in agricultural soil," in Soil Engineering, A. P. Dedousis and T. Bartzanas, Eds., vol. 20 of Soil Biology Series, chapter 13, pp. 195-215, Springer, Berlin, Germany, 2010.

[59] O. Miserque and E. Pirard, "Segregation of the bulk blend fertilizers," Chemometrics and Intelligent Laboratory Systems, vol. 74, no. 1, pp. 215-224, 2004.

[60] M. S. A. Bradley and R. J. Farnish, Segregation of blended fertilisers during spreading: the effect of differences in ballistic properties, Proceeding no. 554, The International Fertiliser Society, York, UK, 2005.

[61] K. F. Kämpfe, H. J. Jäschke, and W. Brinschwitz, "Zusammenhang zwischen wesentlichen physikalischen eigenschaften und der verteilgenauigkeit der mineraldünger bei der application," Agrartechnik, vol. 32, no. 6, pp. 253-256, 1982.

[62] T. P. Hignett, "Physical and chemical properties of fertilizers and methods for their determination," in Fertilizer Manual, T. P. Hignett, Ed., vol. 15 of Developments in Plant and Soil Sciences Series, chapter 22, pp. 284-316, 1985.

[63] UNIDO/IFDC, Fertilizer Manual. International Fertilizer Development Centre, United Nations Industrial Development Organization, Kluwer Academic Publication, Muscle Shoals, Ala, USA, 1998. 
[64] F. T. Nielsson, "Granulation," in Manual of Fertilizer Processing, F. T. Nielsson, Ed., vol. 5 of Fertilizer Science and Technology Series, chapter 9, pp. 159-201, Marcel Dekker, New York, NY, USA, 1987.

[65] A. Aphale, N. Bolander, J. Park, L. Shaw, J. Svec, and C. Wassgren, "Granular fertiliser particle dynamics on and off a spinner spreader," Biosystems Engineering, vol. 85, no. 3, pp. 319329, 2003.

[66] S. Parkin, B. Basford, and P. C. H. Miller, "Spreading accuracy of solid urea fertilisers," DEFRA Report NT2610, 2005, Component Report for DEFRA Project NT26, http://randd.defra .gov.uk/Document.aspx?Document=nt2610_6823_FRP.pdf.

[67] D. L. Antille, L. Gallar-Redondo, and R. J. Godwin, "Determining the particle size range of organomineral fertilisers based on the spreading characteristics of the material," American Society of Agricultural and Biological Engineers, vol. 5, pp. 4251-4268, 2013.

[68] American Society of Agricultural Engineers, Procedure For Measuring Distribution Uniformity and Calibrating Granular Broadcast Spreaders, ASAE, St. Joseph, Mich, USA, 46th edition, 1999, ASAE-S. 341.2. ASAE Standards 1999. 

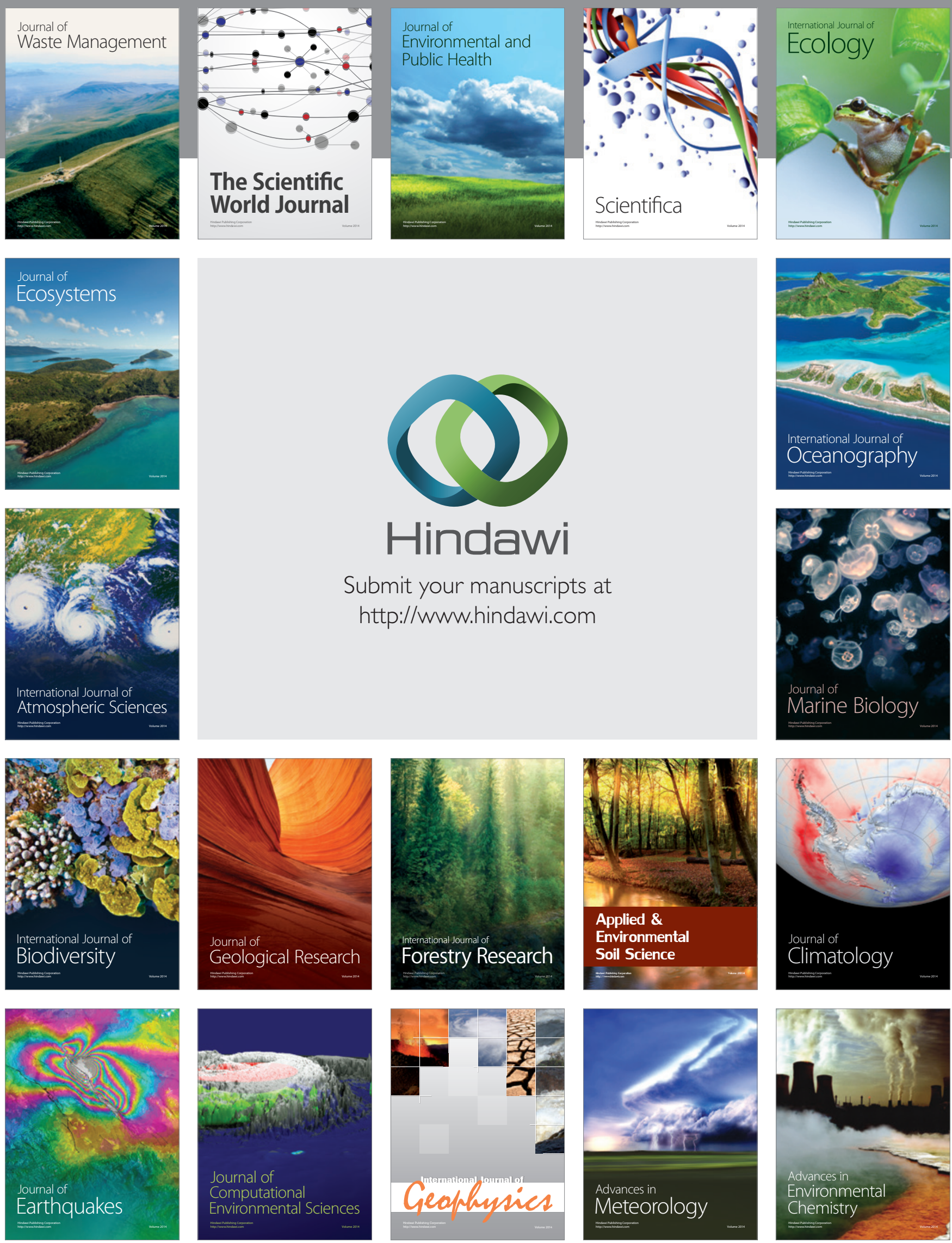